\title{
PENINGKATAN KETERAMPILAN MENYIMAK MELALUI FILM ANIMASI BAGI PESERTA DIDIK KELAS III SEKOLAH DASAR
}

\author{
Fikria Nurfadhilah Yasmine \\ Ratna Trieka Agustina \\ Titis Angga Rini \\ Program Studi Pendidikan Guru Sekolah Dasar, Jurusan Kependidikan Sekolah Dasar dan Prasekolah, \\ Fakultas Ilmu Pendidikan, Universitas Negeri Malang \\ Jl. Semarang No, 5, Malang, Indonesia \\ *E-mail: yasmine.fikria@gmail.com
}

Artikel diterima: 3 September 2020; disetujui: 30 November 2020

\begin{abstract}
This study aims to describe the learning activities and analyze the improvement of listening skills through fable fairy animated film in III A students of Karanganyar State Elementary School 1 Malang Regency. This type of research is classroom action research (CAR) Kemmis and Taggart models. Data collection techniques used were observation, interviews, tests, and documentation. The data analysis technique used is descriptive quantitative and descriptive qualitative. The results showed that fable fairy animated films can improve the listening skills of students in class III A Karanganyar State Elementary School 1 Malang Regency.
\end{abstract}

Keywords: listening skills; animated film; fable

\begin{abstract}
Abstrak: Penelitian ini bertujuan untuk mendeskripsikan kegiatan pembelajaran dan menganalisis peningkatan keterampilan menyimak melalui film animasi fabel pada peserta didik kelas III A SDN Karanganyar 1 Kabupaten Malang. Jenis penelitian ini adalah penelitian tindakan kelas (PTK) dengan model Kemmis dan Taggart. Teknik pengumpulan data yang digunakan adalah pengamatan atau observasi, wawancara, tes, dan dokumentasi. Teknik analisis data yang digunakan adalah deskriptif kuantitatif dan deskriptif kualitatif. Hasil penelitian menunjukkan bahwa film animasi fabel dapat meningkatkan keterampilan menyimak peserta didik kelas III A SDN Karanganyar 1 Kabupatn Malang.
\end{abstract}

Kata kunci: keterampilan menyimak; film animasi; fabel

\section{PENDAHULUAN}

Keterampilan menyimak adalah kemampuan untuk mendengarkan dengan penuh perhatian dan pemahaman. Mendengar berbeda dengan menyimak. Mendengar merupakan kegiatan penerimaan bunyi yang datang tanpa adanya perhatian atau pemahaman dan tahap awal dari menyimak, sedangkan menyimak merupakan kegiatan penerimaan bunyi yang datang dengan adanya perhatian atau pemahaman dan tahap lanjut dari mendengar (Harsiati, 2013). Menyimak 
merupakan aspek keterampilan berbahasa yang paling awal dipelajari oleh manusia. Kemampuan menyimak adalah kemampuan berbahasa pertama yang dimiliki oleh manusia dalam pemerolehan bahasa (Khair, 2018). Pemerolehan bahasa melalui keterampilan berbahasa khususnya aspek menyimak memiliki peran yang sangat penting karena merupakan keterampilan berbahasa yang paling mendasar, akan tetapi sering kali keterampilan menyimak dianggap tidak penting. Walaupun sekolah-sekolah telah lama menuntut pada peserta didik menyimak secara ekstensif, pengajaran langsung bagaimana cara yang terbaik untuk menyimak tetap saja terlupakan dan diabaikan berdasarkan asumsi bahwa keterampilan tersebut merupakan kemampuan alamiah (Fadhlurrahma, 2019).

Berdasarkan hasil studi pendahuluan yang dilaksanakan oleh peneliti pada tanggal 20 Desember 2019 dan 14 Februari 2020 di SDN Karanganyar 1 Kabupaten Malang. Peneliti mendapatkan informasi bahwa peserta didik kelas III A kurang mampu menyimak dengan baik. Informasi tersebut didapat pada saat peneliti melakukan wawancara dengan guru kelas III A SDN Karanganyar 1 Kabupaten Malang. SDN Karanganyar 1 Kabupaten Malang telah melaksanakan gerakan literasi untuk melatih keterampilan berbahasa peserta didik termasuk pada kelas III A, akan tetapi gerakan literasi yang dilaksanakan kurang optimal. Gerakan literasi pada kelas III A SDN Karanganyar 1 Kabupaten Malang dilaksanakan dengan guru meminta peserta didik untuk memilih buku bacaan di sudut baca yang ada di kelas untuk kemudian buku tersebut dibaca atau guru meminta peserta didik untuk menyimak cerita yang disampaikan secara langsung oleh guru, akan tetapi setelah itu guru tidak melakukan tindak lanjut.

Pada kegiatan pembelajaran keterampilan menyimak, peserta didik menyimak cerita yang disampaikan secara langsung oleh guru untuk kemudian dilakukan pembiasaan dengan menanyakan tokoh, latar, dan amanat dari cerita yang telah disimak, akan tetapi hanya sebagian peserta didik yang dapat menjawab tokoh, latar, dan amanat dengan benar. Guru mengetahui bahwa pembelajaran lebih optimal dengan menggunakan media pembelajaran, akan tetapi guru terbiasa untuk tidak menggunakan media pembelajaran dan lebih memilih untuk menyesuaikan bahan simakan dengan kegemaran peserta didik, yaitu fabel. Berdasarkan paparan tersebut, kegiatan melatih keterampilan menyimak dengan guru menyampaikan informasi secara lisan dan peserta didik menyimak informasi tersebut kurang optimal, sehingga perlu dilakukan perbaikan dengan menggunakan media pembelajaran.

Jenis-jenis bahan simakan yang menarik perhatian, yaitu (a) tema mutakhir, (b) tema terarah, sederhana, (c) menambah pengetahuan, (d) bersifat sugestif dan evaluatif, (e) bersifat motivatif dan persuasif, (f) bersifat menghibur, (g) bahasa sederhana mudah dimengerti, dan (h) bersifat dialog. Media pembelajaran merupakan segala sesuatu yang dapat dipakai untuk menyalurkan pesan atau isi pelajaran, merangsang pikiran dan kemampuan peserta didik, 
sehingga dapat mendorong proses belajar mengajar (Kurniaman \& Huda, 2018). Media pembelajaran berupa film dapat melatih keterampilan menyimak peserta didik karena tidak hanya memfasilitasi audio tetapi juga visual, sehingga peserta didik akan lebih fokus untuk menyimak (Alimah, 2020). Film merupakan sederetan gambar dengan ilusi gerak, sehingga terlihat hidup dalam kerangka yang diproyeksikan melalui proyektor dan diproduksi secara mekanis, sehingga dapat dilihat dan didengar (Rubianto, 2018). Film yang dipilih perlu diperhatikan agar bersifat edukasi, sesuai dengan materi pembelajaran yang akan diajarkan, serta sesuai dengan karakteristik dan kegemaran peserta didik.

Penggunaan media film animasi juga mampu membangkitkan rasa ingin tahu, minat peserta didik, dan mampu memotivasi peserta didik untuk lebih giat lagi dalam mengikuti pembelajaran, sehingga peserta didik mampu memahami bahan simakan dengan baik serta mampu mempengaruhi hasil belajar peserta didik (Hartani, 2018). Cerita yang ditampilkan dalam film animasi juga diusahakan agar sesuai dengan kegemaran peserta didik. Fabel sangat digemari peserta didik karena menceritakan mengenai suatu kejadian yang dianggap sebagai khayalan atau tidak benar-benar terjadi (fiksi) yang menceritakan kehidupan hewan yang berperilaku menyerupai manusia (Wati \& Santosa, 2019). Film animasi fabel tepat digunakan sebagai media pembelajaran untuk melatih keterampilan menyimak peserta didik sesuai dengan tahap perkembangan intelektual peserta didik sekolah dasar, yaitu tahap operasional konkrit. Peserta didik tahap operasional konkrit masih mengalami kesulitan besar dalam menyelesaikan tugas-tugas logika (Santrock, 2014). Berdasarkan hal tersebut, peneliti tertarik untuk melakukan penelitian tindakan kelas dengan tujuan mendeskripsikan kegiatan pembelajaran keterampilan menyimak dan menganalisis peningkatan keterampilan menyimak melalui film animasi fabel pada peserta didik kelas III A SDN Karanganyar 1 Kabupaten Malang.

\section{METODE}

Penelitian ini menggunakan penelitian tindakan kelas (PTK) model Kemmis dan Taggart. Penelitian dilaksanakan di kelas III A SDN Karanganyar 1 Kabupaten Malang dengan subjek penelitian peserta didik kelas III A yang berjumlah 24 orang terdiri dari 13 peserta didik lakilaki dan 11 peserta didik perempuan. Data dalam penelitian ini terdiri dari data kualitatif berupa deskripsi pembelajaran keterampilan menyimak melalui film animasi fabel dan data kuantitatif berupa analisis peningkatan keterampilan menyimak melalui film animasi fabel. Sumber data penelitian ini adalah peneliti sebagai pengamat dan dokumentasi, guru kelas dan peserta didik kelas III A. Teknik pengumpulan data yang digunakan adalah pengamatan atau observasi, wawancara, tes, dan dokumentasi. Teknik analisis data yang digunakan adalah deskriptif kuantitatif dan deskriptif kualitatif. Analisis data kuantitatif untuk menghitung peningkatan 
keterampilan menyimak melalui film animasi fabel. Analisis data kualitatif untuk menggambarkan peristiwa yang terjadi selama proses pembelajaran keterampilan menyimak melalui film animasi fabel.

\section{HASIL DAN PEMBAHASAN}

\section{Kegiatan Pembelajaran Keterampilan Menyimak dengan Media Animasi Fabel}

\section{Pelaksanaan Pembelajaran Siklus 1}

Kegiatan tindakan siklus 1 pada penelitian ini dilaksanakan pada kelas III A SDN Karanganyar 1 Kabupaten Malang dengan pengamatan atau observasi, tes, wawancara, dan dokumentasi yang dilaksanakan pada tanggal 26 Februari 2020 pada Tema 6 Energi dan Perubahannya, Subtema 3 Energi Alternatif, Pembelajaran 3, pada muatan Bahasa Indonesia. Kegiatan pendahuluan diawali dengan guru membuka pembelajaran dengan mengucapkan salam dan peserta didik berdoa bersama-sama dengan dipimpin salah satu peserta didik di depan kelas. Guru menanyakan kabar dan mengecek kehadiran peserta didik dengan menanyakan langsung kepada peserta didik. Peserta didik diberikan skemata mengenai pembelajaran keterampilan menyimak yang akan dilaksanakan. Berikut cuplikan tayangan film animasi yang digunakan sebagai media menyimak pada Gambar 1.

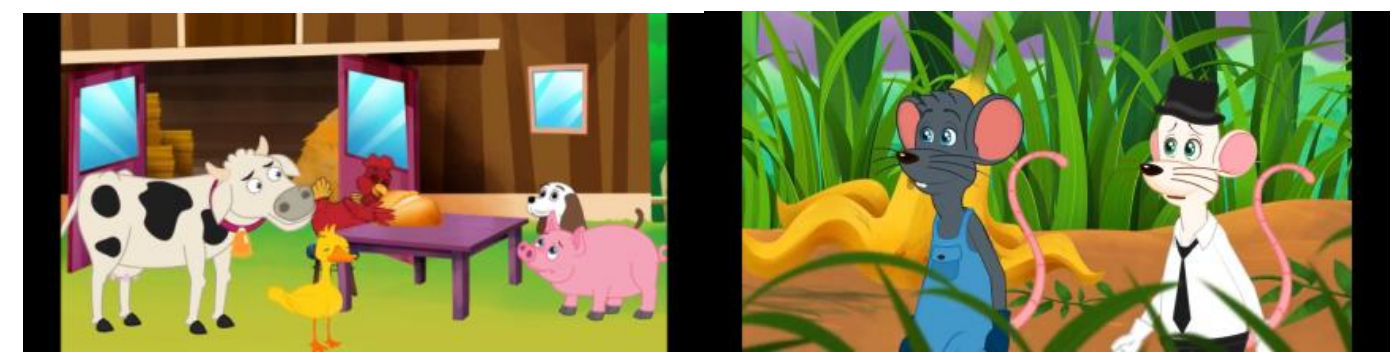

Gambar 1. Media Animasi untuk Menyimak

Guru memberitahukan judul film animasi fabel yang menjadi bahan simakan, yaitu "Sang Ayam Merah Kecil". Tanya jawab mengenai judul film animasi fabel dilakukan antara guru dan peserta didik. Peserta didik dibangkitkan imajinasinya dengan ditunjukkan gambar ayam merah kecil. Guru mengajak peserta didik untuk menebak isi film animasi fabel melalui tanya jawab. Kegiatan inti dilaksanakan dengan peserta didik menyimak film animasi fabel "Sang Ayam Merah Kecil" di dalam kelas bersama-sama. Guru menghentikan penanyangan film animasi fabel pada bagian tertentu yang sesuai dengan materi pembelajaran pada menit ke 02:15 untuk tanya jawab dengan peserta didik.

Peserta didik melanjutkan menyimak film animasi fabel setelah tanya jawab dengan guru. Guru menghentikan penayangan film animasi fabel kembali pada bagian tertentu yang sesuai dengan materi pembelajaran pada menit ke 05:30 untuk tanya jawab dengan peserta didik. 
Peserta didik melanjutkan menyimak film animasi fabel setelah tanya jawab dengan guru. Guru menghentikan penayangan film animasi fabel kembali pada bagian tertentu yang sesuai dengan materi pembelajaran pada menit ke 06:10 untuk tanya jawab dengan peserta didik. Peserta didik melanjutkan menyimak film animasi fabel setelah tanya jawab dengan guru.

Kegiatan penutup (pasca menyimak) dilaksanakan dengan guru mengakhiri penayangan film animasi fabel "Sang Ayam Merah Kecil" dengan hanya satu kali penayangan. Peserta didik diberikan kesempatan untuk menanyakan hal-hal yang belum dimengerti dari kegiatan menyimak film. Tanya jawab mengenai film animasi fabel dilakukan antara guru dan peserta didik. Tanya jawab mengenai pesan dan unsur intrinsik dari film animasi fabel dilakukan oleh guru dan peserta didik. Masing-masing peserta didik diberikan lembar tes evaluasi keterampilan menyimak mengenai pesan dan unsur intrinsik dari film animasi fabel yang telah disimak untuk dikerjakan secara mandiri, kemudian dikumpulkan setelah selesai mengerjakan. Guru menutup pembelajaran dengan terlebih dulu peserta didik berdoa dengan dipimpin salah satu peserta didik di depan kelas, kemudian mengucapkan salam penutup.

Penggunaan film animasi fabel dalam penelitian ini bertujuan untuk meningkatkan keterampilan menyimak peserta didik kelas III A SDN Karanganyar 1 Kabupaten Malang. Media pembelajaran ini dapat mengarahkan perhatian peserta didik untuk tetap fokus mengamati dan menyimak informasi yang disampaikan karena memiliki unsur bunyi atau suara dan unsur gambar dengan menyajikan gambar tokoh-tokoh yang penuh warna dan cerita yang sederhana disertai dengan suara tokoh-tokoh yang ceria dan musik yang menyenangkan. Selain itu film animasi tidak hanya melatih keterampilan berbahasa peserta didik, tetapi juga melatih imajinasi dan budi pekerti. Keuntungan penggunaan media pembelajaran diantaranya, (a) pembelajaran bahasa lebih menarik atau menumbuhkan rasa cinta terhadap pelajaran bahasa; (b) menambah minat belajar pebelajar, minat yang baik akan menghasilkan mutu yang baik pula (prestasi belajar); (c) mempermudah dan memperjelas materi pelajaran; (d) memperingan tugas pengajaran; (e) merangsang daya kreasi; dan (f) pembelajaran tidak monoton sehingga tidak membosankan (Mahmudah, 2018).

Penerapan film animasi fabel dalam meningkatkan keterampilan menyimak peserta didik menggunakan metode pembelajaran dan strategi pembelajaran keterampilan menyimak yang disesuaikan dengan karakteristik peserta didik, yaitu metode pembelajaran simak cerita dan strategi pembelajaran Direct Listening Thinking and Activity (DLTA). Menurut Faris (Oktaviano, 2013) strategi DLTA berperan penting dalam pembelajaran menyimak karena peserta didik dapat terampil dalam berfikir kritis, membangun imajinasi, memprediksi cerita selanjutnya sesuai dengan pengetahuan sebelumnya, dan pengalaman peserta didik untuk memahami cerita tersebut (Rini \& Cahyanto, 2020). Berkaitan dengan kegiatan siklus 1 yang 
dilakukan di kelas IIIA diperoleh hasil dalam mengerjakan tes evaluasi yang berkaitan dengan kegiatan menyimak yang ditunjukkan pada Tabel 1.

Tabel 1. Hasil Tes Evaluasi Keterampilan Menyimak Siklus 1

\begin{tabular}{clll}
\hline No. & Nama & Nilai & Kriteria \\
\hline 1. & MRYP & 56,25 & $\mathrm{C}$ \\
2. & MRR & 81,25 & $\mathrm{~A}$ \\
3. & MSHS & 65,625 & $\mathrm{~B}$ \\
4. & MZA & 67,5 & $\mathrm{~B}$ \\
5. & MZM & 87,5 & $\mathrm{~A}$ \\
6. & NVV & 62,5 & $\mathrm{C}$ \\
7. & NPR & 73,75 & $\mathrm{~B}$ \\
8. & RIS & 100 & $\mathrm{~A}$ \\
9. & RDA & 81,25 & $\mathrm{~A}$ \\
10. & RABAF & 59,375 & $\mathrm{C}$ \\
11. & REP & 93,75 & $\mathrm{~A}$ \\
12. & RSP & 50 & $\mathrm{D}$ \\
13. & RNS & 81,25 & $\mathrm{~A}$ \\
14. & RDI & 56,25 & $\mathrm{C}$ \\
15. & ST & 96,875 & $\mathrm{~A}$ \\
16. & SW & 43,75 & $\mathrm{D}$ \\
17. & SNA & 87,5 & $\mathrm{~A}$ \\
18. & TK & 56,25 & $\mathrm{C}$ \\
19. & VR & 81,25 & $\mathrm{~A}$ \\
20. & VDN & 56,25 & $\mathrm{C}$ \\
21. & ZSW & 40,625 & $\mathrm{D}$ \\
22. & ZAA & 100 & $\mathrm{~A}$ \\
23. & DY & 68,75 & $\mathrm{~B}$ \\
24. & A & 6,25 & $\mathrm{E}$ \\
\hline & & $\mathbf{6 8 , 9}$ & $\mathrm{B}$ \\
\hline & & & \\
\hline
\end{tabular}

Hasil penelitian menunjukkan bahwa keterampilan menyimak peserta didik mencapai ratarata nilai peserta didik mencapai 68,9 . Berikut sajian data hasil tes evaluasi keterampilan menyimak siklus pertama. Ketuntasan individu dicapai $41,66 \%$ peserta didik dan ketuntasan klasikal belum tercapai. Berdasarkan hasil refleksi dan hasil tes evaluasi keterampilan menyimak siklus 1 tersebut masih perlu dilakukan suatu perbaikan untuk pembelajaran keterampilan menyimak melalui film animasi fabel untuk meningkatkan ketermpilan menyimak peserta didik kelas III A SDN Karanganyar 1 Kabupaten Malang pada siklus 2. Guru dan peneliti menyimpulkan bahwa keterampilan menyimak peserta didik kelas III A SDN Karanganyar 1 Kabupaten Malang meningkat melalui penggunaan film animasi fabel dilihat dari ketuntasan individu dicapai $41,66 \%$ peserta didik atau 10 peserta didik dari 24 peserta didik dalam satu kelas dan kentuntasan klasikal belum tercapai dengan nilai rata-rata kelas 68,906.

Hasil penelitian ini menunjukkan bahwa selama siklus pertama dapat diamati dampak dari pemanfaatan media animasi fabel untuk keterampilan menyimak. Hasil penelitian ini selaras dengan penelitian Hakim (2018) menunjukkan bahwa media film berdampak positif terhadap keterampilan menyimak. Keterampilan menyimak sendiri merupakan kemampuan untuk menerima bunyi oleh indera pendengaran dengan penuh perhatian dan pemahaman yang 
memiliki peran yang sangat penting karena merupakan keterampilan berbahasa yang paling mendasar (Pebriana dkk., 2017). Keterampilan menyimak sendiri diantaranya ada (a) menyimak berkembang secara alami; (b) guru kurang mendapat pelatihan dalam pelajaran menyimak; (c) perilaku menyimak yang tersembunyi sehingga sulit diamati; dan (d) kegiatan sekolah terlalu padat sehingga menyimak tidak diperhatikan. Hal tersebut dibuktikan dengan nilai rata-rata kelas keterampilan menyimak peserta didik hanya mencapai 55,078 dengan kriteria D (kurang).

Pembelajaran keterampilan menyimak juga berjalan kurang optimal karena metode dan strategi pembelajaran yang digunakan adalah guru membacakan teks secara langsung, kemudian peserta didik menyimak teks yang dibacakan, dan setelah itu dilakukan tindak lanjut dengan mengerjakan tes evaluasi berdasarkan teks yang telah disimak tanpa menggunakan media pembelajaran. Hal ini dapat disimpulkan bahwa keterampilan menyimak peserta didik kelas III A SDN Karanganyar 1 Kabupaten Malang perlu diperbaiki dengan inovasi dalam media pembelajaran untuk meningkatkan keterampilan menyimak peserta didik. Media ini akan berdampak pada keterampilan menyimak untuk membantu peserta didik dalam menerima informasi secara lisan dan dalam suasana yang menyenangkan (Hakim, 2018).

\section{Pelaksanaan Pembelajaran Siklus 2}

Kegiatan pendahuluan (pra menyimak) diawali dengan guru membuka pembelajaran dengan mengucapkan salam dan peserta didik berdoa bersama-sama dengan dipimpin salah satu peserta didik di depan kelas. Guru menanyakan kabar dan mengecek kehadiran peserta didik dengan menanyakan langsung kepada peserta didik. Peserta didik diberikan skemata mengenai pembelajaran keterampilan menyimak yang akan dilaksanakan. Guru memberitahukan judul film animasi fabel yang menjadi bahan simakan, yaitu "Tikus Desa dan Tikus Kota". Tanya jawab mengenai judul film animasi fabel dilakukan antara guru dan peserta didik. Peserta didik dibangkitkan imajinasinya dengan ditunjukkan gambar ayam merah kecil. Guru mengajak peserta didik untuk menebak isi film animasi fabel. Potret peserta didik saat menyimak film animasi ditunjukkan pada Gambar 2.

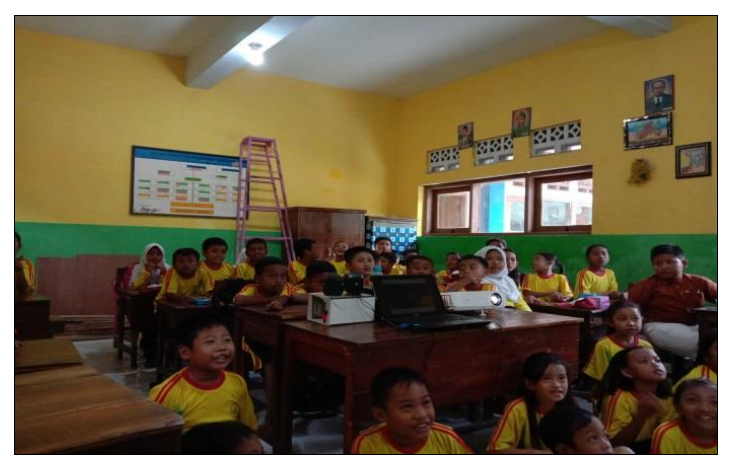

Gambar 2. Peserta Didik Menyimak Tayangan Video 
Kegiatan inti (menyimak) dilakukan dengan peserta didik menyimak film animasi fabel di dalam kelas dengan duduk di bangku masing-masing. Guru mengakhiri penanyangan film animasi fabel dan menunjukkan potongan gambar yang sesuai dengan materi pembelajaran pada menit ke 03:30 untuk tanya jawab dengan peserta didik. Peserta didik menyimak kembali film animasi fabel untuk kedua kalinya. Guru mengakhiri penanyangan film animasi fabel untuk kedua kalinya.

Kegiatan penutup (pasca menyimak) dilaksanakan dengan memberikan kesempatan pada peserta didik untuk menanyakan hal-hal yang belum dimengerti dari kegiatan menyimak film animasi fabel. Tanya jawab mengenai film animasi fabel dilakukan antara guru dan peserta didik. Tanya jawab mengenai pesan dan unsur intrinsik dari film animasi fabel dilakukan oleh guru dan peserta didik. Masing-masing peserta didik diberikan lembar tes evaluasi keterampilan menyimak mengenai pesan dan unsur intrinsik dari film animasi fabel "Tikus Desa dan Tikus Kota" yang telah disimak untuk dikerjakan secara mandiri, kemudian dikumpulkan setelah selesai mengerjakan. Guru menutup pembelajaran dengan terlebih dulu peserta didik berdoa dengan dipimpin salah satu peserta didik di depan kelas, kemudian mengucapkan salam penutup. Berkaitan dengan kegiatan siklus 2 yang dilakukan di kelas IIIA diperoleh hasil dalam mengerjakan tes evaluasi yang berkaitan dengan kegiatan menyimak yang ditunjukkan pada Tabel 2.

Tabel 2. Hasil Tes Evaluasi Keterampilan Menyimak Siklus 1

\begin{tabular}{|c|c|c|c|}
\hline No. & Nama & Nilai & Kriteria \\
\hline 1. & MRYP & 96,6 & A \\
\hline 2. & MRR & 93,3 & A \\
\hline 3. & MSHS & 80 & A \\
\hline 4. & MZA & 93,3 & A \\
\hline 5. & MZM & 86,6 & A \\
\hline 6. & NVV & 73,3 & B \\
\hline 7. & NPR & 83,3 & A \\
\hline 8. & RIS & 100 & A \\
\hline 9. & RDA & 93,3 & A \\
\hline 10. & RABAF & 86,6 & A \\
\hline 11. & REP & 93,3 & A \\
\hline 12. & RSP & 66,6 & B \\
\hline 13. & RNS & 80 & A \\
\hline 14. & RDI & 63,3 & C \\
\hline 15. & ST & 93.3 & A \\
\hline 16. & SW & 36,6 & E \\
\hline 17. & SNA & 100 & A \\
\hline 18. & TK & 100 & A \\
\hline 19. & VR & 100 & A \\
\hline 20. & VDN & 86,6 & A \\
\hline 21. & ZSW & 86,6 & A \\
\hline 22. & ZAA & 100 & A \\
\hline 23. & DY & 83,3 & A \\
\hline 24. & A & 30 & E \\
\hline \multicolumn{2}{|r|}{ Rata-rata } & 83,69 & $\mathbf{A}$ \\
\hline
\end{tabular}


Hasil pelaksanaan sikuls kedua menunjukkan bahwa kemampuan menyimak peserta didik mengalami peningkatan dari siklus pertama dengan rata-rata 83,69. Berdasarkan hasil refleksi dan hasil tes evaluasi keterampilan menyimak siklus kedua, dapat ditarik kesimpulan bahwa tidak perlu dilakukan perbaikan untuk pembelajaran keterampilan menyimak melalui film animasi fabel untuk meningkatkan keterampilan menyimak peserta didik kelas III A SDN Karanganyar 1 Kabupaten Malang pada siklus 3. Guru dan peneliti menyimpulkan bahwa keterampilan menyimak peserta didik kelas III A SDN Karanganyar 1 Kabupaten Malang meningkat melalui penggunaan film animasi fabel dilihat dari ketuntasan individu yang dicapai 79,16\% peserta didik atau 19 peserta didik dari 24 peserta didik dalam satu kelas, dan kentuntasan klasikal yang tercapai dengan nilai rata-rata kelas 83,69. Potret peserta didik saat mengerjakan tes evaluasi ditunjukkan pada Gambar 3.

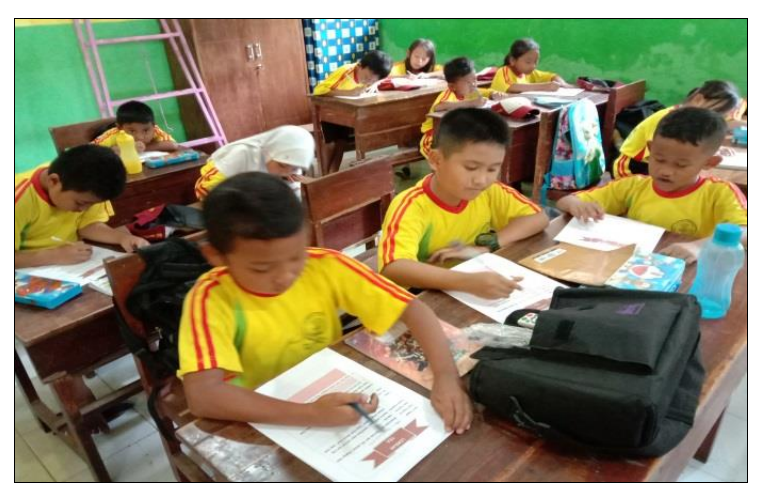

Gambar 3. Peserta Didik Mengerjakan Tes Evaluasi

Dari peningkatan ini menunjukkan bahwa film animasi dongeng tepat untuk digunakan dalam pembelajaran menyimak. Hasil penelitian menunjukkan video efektif untuk digunakan untuk pembelajaran menyimak (Sajrina dkk., 2017). Film animasi dongeng fabel merupakan rangkaian gambar tak hidup yang berurutan pada frame dan diproyeksikan secara mekanis elektronis. Gambar tampak hidup pada layar yang menceritakan mengenai suatu kejadian yang dianggap sebagai khayalan atau tidak benar-benar terjadi (fiksi), yang menceritakan kehidupan hewan yang berperilaku menyerupai manusia (Pratiwi, 2015). Penerapan film animasi dongeng fabel dalam meningkatkan keterampilan menyimak peserta didik menggunakan metode pembelajaran dan strategi pembelajaran keterampilan menyimak yang disesuaikan dengan karakteristik peserta didik, yaitu metode pembelajaran simak cerita dan strategi pembelajaran Direct Listening Thinking and Activity (DLTA).

\section{Peningkatan Keterampilan Menyimak dengan Media Animasi Fabel}

Setelah menerapkan film animasi fabel pada siklus 1 menunjukkan bahwa kemampuan menyimak peserta didik mengalami peningkatan dengan memiliki kriteria nilai rata-rata kelas $\mathrm{B}$ (baik) terdiri dari $41,66 \%$ peserta didik dengan kriteria A (baik sekali), 16,66\% peserta didik 
dengan kriteria B (baik), 25\% peserta didik dengan kriteria C (cukup), 12,5\% peserta didik dengan kriteria D (kurang), dan 4,16\% peserta didik dengan kriteria E (kurang sekali). Ketuntasan individu dicapai 10 peserta didik dan ketuntasan klasikal belum tercapai, sehingga masih perlu dilakukan suatu perbaikan untuk pembelajaran keterampilan menyimak melalui film animasi fabel untuk meningkatkan ketermpilan menyimak peserta didik dilihat dari ketuntasan individu yang dicapai $41,66 \%$ peserta didik atau 10 dari 24 peserta didik dalam satu kelas.

Setelah merefleksi tindakan pada siklus 1, menerapkan film animasi fabel pada siklus 2 menunjukkan bahwa kemampuan menyimak peserta didik mengalami peningkatan dengan memiliki kriteria nilai rata-rata kelas A (baik sekali) terdiri dari $79,16 \%$ peserta didik dengan kriteria A (baik sekali), 8,33\% peserta didik dengan kriteria B (baik), 4,16\% peserta didik dengan kriteria C (cukup), dan 8,33\% peserta didik dengan kriteria E (kurang sekali). Ketuntasan individu dicapai 19 peserta didik dan ketuntasan klasikal telah tercapai, sehingga tidak perlu dilakukan suatu perbaikan untuk pembelajaran keterampilan menyimak melalui film animasi fabel untuk meningkatkan keterampilan menyimak peserta didik dilihat dari ketuntasan individu yang dicapai 79,16\% peserta didik atau 19 dari 24 peserta didik dalam satu kelas. Data rata-rata nilai keterampilan menyimak peserta didik selama penelitian ini ditunjukkan pada Tabel 3.

Tabel 3. Rata-rata Nilai Setiap Siklus Penelitian

\begin{tabular}{cccl}
\hline No. & Pelaksanaan Tindakan & Nilai Rata-Rata & \multicolumn{1}{c}{ Kriteria } \\
\hline 1. & Pra Tindakan & 55,078 & D (Kurang) \\
2. & Siklus 1 & 68,906 & B (Baik) \\
3. & Siklus 2 & 83,69 & A (Baik Sekali) \\
\hline
\end{tabular}

Peningkatan yang ditunjukkan dalam penelitian ini menunjukkan bahwa media animasi fabel dapat digunakan dalam pembelajaran menyimak. Film merupakan salah satu media audio visual yang dapat menampilkan rangkaian gambar bergerak disertai dengan bunyi atau suara. Film merupakan sederetan gambar dengan ilusi gerak, sehingga terlihat hidup dalam frame yang diproyeksikan melalui proyektor dan diproduksi secara mekanis, sehingga dapat dilihat dan didengar. Film memiliki kelebihan dari audio dan visual dalam penyampaian pesan atau informasi secara lisan (Adittia, 2017). Film ini juga menarik untuk digunakan di sekolah dasar karena usia peserta didik pada operasional konkret dan memiliki ketertarikan pada simbol-simbol visual (Wuryanti \& Kartowagiran, 2016). Pada penelitian ini, film yang digunakan menggunakan jenis dongen fabel debgan cerita-cerita ringan yang tentunya sesuai untuk anak usia sekolah dasar (Hasmi, 2017). Dongeng fabel merupakan dongeng yang paling menarik bagi anak-anak karena berbeda dengan jenis dongeng lainnya yang tokohnya adalah manusia, dongeng fabel tokohnya adalah hewan yang bertingkah laku seperti manusia (Karyadi, 2018). Hasil penelitian lain juga menunjukkan bahwa pemanfaatan media fabel dalam pembelajaran di sekolah dasar memudahkan penyampaian materi (Darna, 2018). 


\section{SIMPULAN DAN SARAN}

\section{Simpulan}

Penerapan film animasi dongeng fabel dapat meningkatkan keterampilan menyimak peserta didik kelas III A SDN Karanganyar 1 Kabupaten Malang yang dibuktikan dengan keterampilan menyimak peserta didik kelas III A SDN Karanganyar 1 Kabupaten Malang yang mengalami peningkatan. Hasil penelitian menunjukkan bahwa pada siklus 1 kemampuan menyimak peserta didik mengalami peningkatan dengan nilai rata-rata kelas 68,906 dengan kriteria nilai rata-rata kelas B (baik). Pada siklus 2 kemampuan menyimak peserta didik mengalami peningkatan dengan nilai rata-rata kelas 83,69 dengan kriteria nilai rata-rata kelas A (baik sekali).

\section{Saran}

Berdasarkan penelitian ini diajukan beberapa saran diantaranya sebagai berikut. Bagi guru dapat menjadikan hasil penelitian ini sebagai pedoman untuk melaksanakan pembelajaran keterampilan menyimak dengan menerapkan film animasi dongeng fabel sebagai media yang digemari oleh peserta didik dan dapat digunakan dalam pembelajaran menyimak. Bagi peneliti lain dapat menjadikan hasil penelitian ini sebagai masukan untuk meneliti tentang keterampilan menyimak dan pemanfaatan film animasi dongeng fabel dalam pembelajaran menyimak selanjutnya dalam eksperimen, pengembangan, maupun penelitian tindakan kelas yang relevan.

\section{DAFTAR RUJUKAN}

Adittia, A. (2017). Penggunaan Media Pembelajaran Audio Visual untuk Meningkatkan Hasil Belajar IPS pada Peserta Didik Kelas IV SD. Mimbar Sekolah Dasar, 4(1). https://doi.org/10.23819/mimbar-sd.v4i1.5227

Alimah, N. (2020). Penerapan Media Pembelajaran Video Animasi untuk Meningkatkan Keterampilan Memperkenalkan Anggota Keluarga dalam Pembelajaran Bahasa Indonesia pada Peserta Didik Kelas I SDI Alfattah Kecamatan Banjarsari Kota Surakarta Tahun Pelajaran 2020/2021. JP3 (Jurnal Pendidikan Dan Profesi Pendidik), 6(1). https://doi.org/10.26877/jp3.v6i1.7299

Darna, D. (2018). Peningkatan Keterampilan Mendengarkan Cerita Anak Melalui Media Audio Visual pada Peserta Didik Kelas I SDN 020 Kualu Nenas Kecamatan Tambang Kabupaten Kampar. Jurnal Pajar (Pendidikan Dan Pengajaran), 2(2), 194. https://doi.org/10.33578/pjr.v2i2.5067

Fadhlurrahma, F. (2019). Keterampilan Berbahasa: Menyimak Berita. https://doi.org/10.31227/osf.io/9xdvg

Hakim, M. N. (2018). Penerapan Media Audiovisual dalam Meningkatkan Keterampilan Menyimak Dongeng Peserta didik Kelas III MIS Darul Ulum Muhammadiyah Bulukumba. Silampari Bisa: Jurnal Penelitian Pendidikan Bahasa Indonesia, Daerah, Dan Asing, 1(2), 1-16. https://doi.org/10.31540/silamparibisa.v1i2.79

Harsiati, T. (2013). Asesmen Pembelajaran Bahasa Indonesia. UM Press.

Hartani, A. (2018). Peningkatan Kualitas Pembelajaran Menyimak Cerita Pendek Melalui Model Picture and Picture Berbantuan Media CD Cerita pada Peserta didik Kelas V SD 1 Mejobo 
Kudus. KREDO: Jurnal Ilmiah Bahasa Dan Sastra, 2(1). https://doi.org/10.24176/kredo.v2i1.2576

Hasmi, F. (2017). Peningkatan Keterampilan Membaca Permulaan dengan Menggunakan Media Kartu Kata pada Peserta didik Kelas II SD Negeri 001 Rimba Sekampung Dumai. School Education Journal PGSD FIP UNIMED, 7(4), 423-428. https://doi.org/10.24114/sejpgsd.v7i4.8096

Karyadi, A. C. (2018). Peningkatan Keterampilan Berbicara Melalui Metode Storytelling Menggunakan Media Big Book. Jurnal Pengabdian Masyarakat (JPM-IKP), 1(02). https://doi.org/10.31326/jmp-ikp.v1i02.70

Khair, U. (2018). Pembelajaran Bahasa Indonesia dan Sastra (BASASTRA) di SD dan MI. ARRIAYAH : Jurnal Pendidikan Dasar, 2(1), 81. https://doi.org/10.29240/jpd.v2i1.261

Kurniaman, O., \& Huda, M. N. (2018). Penerapan Strategi Bercerita untuk Meningkatkan Keterampilan Menyimak Peserta didik Kelas III SD Muhamadiyah 6 Pekanbaru. Primary: $\begin{array}{lllll}\text { Jurnal Pendidikan Guru Sekolah } & 249 .\end{array}$ https://doi.org/10.33578/jpfkip.v7i2.6284

Mahmudah, M. (2018). Pengaruh Media Audio Terhadap Keterampilan Menyimak dan Berbicara Bahasa Arab. Jurnal Tarbiyah: Jurnal Ilmiah Kependidikan, 7(2). https://doi.org/10.18592/tarbiyah.v7i2.2219

Oktaviani, Rizka Nur. 2013. Penerapan Strategi Directed Listening And Thinking Activity (DLTA) untuk Meningkatkan Keterampilan Menyimak Cerita Siswa Kelas V Sekolah Dasar. Jurnal Penelitian Pendidikan Guru Sekolah Dasar, 1(2), 1-10.

Pebriana, U., Ekowati, D. W. W., \& Fantiro, F. A. (2017). Peningkatan Keterampilan Menyimak Melalui Model Pembelajaran Artikulasi dan Media Boneka Tangan pada Pembelajaran Tematik Kelas 1 SDN Pejok II Kedungadem Bojonegoro. Jurnal Pemikiran Dan

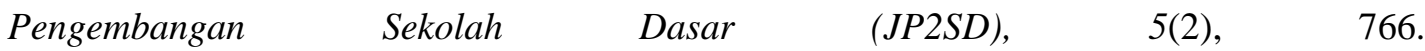
https://doi.org/10.22219/jp2sd.v5i2.4826

Pratiwi, Y. (2015). Penggunaan Strategi Representasi Visual dalam Pembelajaran Apresiasi Prosa Fiksi. Diksi, 13(2). https://doi.org/10.21831/diksi.v13i2.6451

Rini, T. A., \& Cahyanto, B. (2020). Supporting Elementary Students Creative Writing Skill With Assessment as Learning. Proceedings of the 2nd Early Childhood and Primary Childhood Education (ECPE 2020). 2nd Early Childhood and Primary Childhood Education (ECPE 2020), Malang, Indonesia. https://doi.org/10.2991/assehr.k.201112.010

Rubianto, R. (2018). Peningkatan Kemampuan Menyimak Bahasa Indonesia melalui Penggunaan Media Audio pada Murid Kelas V. JKPD (Jurnal Kajian Pendidikan Dasar), 2(1), 292. https://doi.org/10.26618/jkpd.v2i1.1086

Santrock, J. W. (2014). Psikologi Pendidikan. Salemba Humanika.

Sri Sajrina, E., Chamalah, E., \& Arsanti, M. (2017). Peningkatan Keterampilan Menyimak Dengan Model Pembelajaran Savi dan Media Video Interaktif pada Peserta Didik Kelas XI MA. Edusentris, 3(2), 200. https://doi.org/10.17509/edusentris.v3i2.218

Wati, H. S., \& Santosa, W. H. (2019). Keefektifan Penggunaan Media Papan Cerita dalam Pembelajaran Menulis Teks Fabel pada Kelas VII MTs Yapi Pakem Sleman Yogyakarta Tahun Pelajaran. Caraka, 5(2), 29. https://doi.org/10.30738/caraka.v5i2.4830

Wuryanti, U., \& Kartowagiran, B. (2016). Pengembangan Media Video Animasi untuk Meningkatkan Motivasi Belajar dan Karakter Kerja Keras Peserta Didik Sekolah Dasar. Jurnal Pendidikan Karakter, 6(2). https://doi.org/10.21831/jpk.v6i2.12055 